\title{
Hydrophobic and Haemagglutinating Properties of Renibacterium salmoninarum
}

\author{
By JAMES G. DALY AND ROSELYNN M. W. STEVENSON* \\ Department of Microbiology, College of Biological Science, University of Guelph, Guelph, \\ Ontario, Canada NIG 2WI
}

(Received 18 June 1987)

\begin{abstract}
Twenty-five strains of Renibacterium salmoninarum, from diverse geographical locations, were all hydrophobic when tested by ammonium sulphate aggregation and adherence to hydrocarbons. In addition, all strains caused haemagglutination of rabbit erythrocytes, but not of erythrocytes from salmonid fish. The hydrophobic and haemagglutinating properties were further characterized for $R$. salmoninarum ATCC 33209 (the type strain). Treating the bacteria with protease $\mathrm{K}$ or trypsin decreased hydrophobicity but had no effect on the ability to haemagglutinate rabbit erythrocytes. Heating the bacteria to 62 or $100^{\circ} \mathrm{C}$ reduced hydrophobicity and removed the haemagglutinin from the cell surface. The haemagglutinin may be the heat-stable bacterial antigen extracted from the tissue of infected fish in serodiagnostic procedures.
\end{abstract}

\section{INTRODUCTION}

Renibacterium salmoninarum is the Gram-positive bacterium that causes bacterial kidney disease (BKD) of salmonid fish (Sanders \& Fryer, 1980). BKD is transmitted via the eggs of infected adults, and at present no completely successful antibiotic or vaccination regimes are available to cure fish of the disease. Thus, for fish health management, adult brood fish must be screened for the presence of $R$. salmoninarum. The bacterium grows only slowly in culture, requiring about $10 \mathrm{~d}$ to grow from heavy inocula and 4-6 weeks from dilute inocula (Fryer \& Sanders, 1981); detection methods based on culture are thus impractical and serological methods are routinely used. Many different serological procedures are used, including immunodiffusion (Chen et al., 1974) and counterimmunodiffusion (Cipriano et al., 1985), immunofluorescence (Bullock et al., 1974; Evelyn et al., 1981), co-agglutination (Kimura \& Yoshimizu, 1981), and ELISA (Pascho \& Mulcahy, 1987; Sakai et al., 1987). However, in these tests, the bacterial antigens being detected are uncharacterized, and cross-reactions with other bacteria have been reported (Austin et al., 1985; Fiedler \& Draxl, 1986). These cross-reactions may occur because of serum antigens present in the KDM-2 medium used to grow $R$. salmoninarum (Evelyn, 1977). Such problems can be avoided by using a serum-free charcoal agar, KDM-C (Daly \& Stevenson, 1985).

Some observations reported in the literature suggest that the cell surface of $R$. salmoninarum could be hydrophobic. First, the bacteria autoaggregate in normal serum, but heating to $62{ }^{\circ} \mathrm{C}$ overcomes this (Evelyn et al., 1973). Second, Smith (1964) reported that the original Dee strain of $R$. salmoninarum formed a pellicle in broth; other authors have also noted a tendency for aggregation, in a variety of broth media (Evelyn et al., 1973; Embley et al., 1982; McCarthy et al., 1984). There would be advantage to $R$. salmoninarum in being hydrophobic. The bacterium is believed to survive in the macrophages of diseased fish (Young \& Chapman, 1978), and cells with a hydrophobic surface are more likely to be taken up by macrophages (Van Oss, 1978). In this paper we report the hydrophobic and haemagglutinating properties of 25 strains of $R$. salmoninarum from diverse geographic localities.

Abbreviations: BATH, bacterial adherence to hydrocarbons; SAT, salt aggregation test. 
Table 1. Strains of $R$. salmoninarum tested for hydrophobicity and haemagglutination activity

\begin{tabular}{lll}
\multicolumn{1}{c}{ Strain } & \multicolumn{1}{c}{ Isolation origin* } & Source \\
$\begin{array}{r}\text { ATCC 33209 } \\
\text { (type strain) }\end{array}$ & Chinook salmon, Oregon & ATCC \\
ATCC 33739 & Brook trout & ATCC \\
NCMB 1111 & Salmo sp., USA & NCMB \\
NCMB 1114 & Atlantic salmon, Scotland & NCMB \\
RS22 & Atlantic salmon, Nova Scotia & AH \\
DR-128 & Rainbow trout, British Columbia & PBS \\
MT241 & Coho salmon, France & DAFS \\
JD17 & Rainbow trout, Manitoba & FWI \\
FQ-1 & Brook trout, Saskatchewan & FWI \\
WS-1K-GL & Lake trout, Manitoba & FWI \\
Sock-3 & Sockeye salmon, Manitoba & FWI \\
Char & Arctic char, Northwest Territories & FWI \\
$2 / 2 / 79,20 / 2 / 79$, & Rainbow trout, England & WRL \\
$27 / 7 / 78,26 / 3 / 80$, & & \\
$28 / 2 / 80$ & & DMG \\
JD19 & & DMG \\
NFLD & Rainbow trout, Ontario & DMG \\
NB & Atlantic salmon (Ouananiche), Newfoundland & DMG \\
Moc & Atlantic salmon, New Brunswick & DMG \\
BC & Brook trout, Ontario & DMG \\
Coho & Coho salmon, British Columbia & DMG \\
503 & Coho salmon, Ontario & DMG \\
SP & Brook trout, Ontario &
\end{tabular}

- The Latin names of the fish are as follows: Arctic char, Salvelinus alpinus; Atlantic salmon, Salmo salar; brook trout, Salvelinus fontinalis; chinook salmon, Oncorhynchus tschawytscha; coho salmon, Oncorhynchus kisutch; lake trout, Salvelinus namaycush; rainbow trout, Salmo gairdneri; sockeye salmon, Oncorhynchus nerka.

† ATCC, American Type Culture Collection, Rockville, Md, USA ; NCMB, National Collection of Industrial and Marine Bacteria, Aberdeen, UK; DAFS, D. Bruno, Department of Agriculture and Fisheries for Scotland, Aberdeen, UK; PBS, T. P. T. Evelyn, Department of Fisheries and Oceans, Pacific Biological Station, Nanaimo, Canada; AH, W. D. Paterson, Aqua Health Ltd, Willowdale, Ontario, Canada; FWI, B. Souter, Freshwater Institute, Winnipeg, Manitoba, Canada; WRL, B. Spacey, Wellcome Research Laboratory, Beckenham, Kent, UK; DMG, Department of Microbiology, University of Guelph, Ontario, Canada.

\section{METHODS}

Bacterial strains and growth. The 25 strains of $R$. salmoninarum examined and their sources are given in Table 1 . They were grown in biphasic culture on slants of serum-free charcoal agar (KDM-C), using $50 \mathrm{ml}$ agar per slant, overlaid with $5 \mathrm{ml} 0.1 \%$ peptone in $0.85 \% \mathrm{NaCl}$ (Daly \& Stevenson, 1985). Cultures were incubated for $10 \mathrm{~d}$ to 2 weeks at $15^{\circ} \mathrm{C}$, until dense growth was present in the liquid phase. The bacteria were washed three times in saline before being analysed or treated.

Heat and enzyme treatments. The type strain of $R$. salmoninarum, ATCC 33209, was suspended in saline such that a 50 -fold dilution would give an $\mathrm{OD}_{600}$ of $0 \cdot 16$ (Bauch \& Lomb, Spectronic 70). The suspension, in a screwcapped test tube, was placed in a steamer for 20 or $40 \mathrm{~min}$, or at $62^{\circ} \mathrm{C}$ for $40 \mathrm{~min}$. After heating, the bacteria were centrifuged at $4^{\circ} \mathrm{C}$ and resuspended in saline to give the same concentration of bacteria. For enzyme treatments, $R$. salmoninarum ATCC 33209 was suspended in buffer $(40 \mathrm{~mm}$-sodium phosphate, $150 \mathrm{~mm}$-sodium chloride, $\mathrm{pH} 7.2$ ) at a similar density as above. Trypsin or protease $\mathrm{K}$ (Sigma) at a concentration of $1 \mathrm{mg} \mathrm{ml}^{-1}$ was added to the bacteria and allowed to react for $3 \mathrm{~h}$. The bacteria were then centrifuged at $4{ }^{\circ} \mathrm{C}$ and resuspended in saline to the original cell densities.

Haemagglutination. Rabbit erythrocytes from New Zealand White rabbits were obtained by venipuncture of the ear and collected in Alsever's solution (containing, per litre: $20.5 \mathrm{~g}$ glucose, $8.0 \mathrm{~g}$ sodium citrate dihydrate, $0.55 \mathrm{~g}$ citric acid and $4.2 \mathrm{~g} \mathrm{NaCl}$ ). Blood was taken by caudal venipuncture from brook trout (Salvelinus fontinalis), coho salmon (Oncorhynchus kisutch) and rainbow trout (Salmo gairdneri) and placed in Alsever's solution. All other blood was purchased from Woodlyn Labs (Guelph, Ontario) as suspensions in Alsever's solution. All erythrocytes were washed three times in saline, stored at $4^{\circ} \mathrm{C}$ and used within one week.

Strains of $\boldsymbol{R}$. salmoninarum were tested for haemagglutination of rabbit erythrocytes by making a thick suspension of bacteria in saline (approximating an $\mathrm{OD}_{600}$ of 5) and reacting $25 \mu$ l of this solution with $25 \mu 13 \%$ (v/v) erythrocytes on a glass slide. The liquid phase of the growth medium was also tested for haemagglutinating activity. Haemagglutination by $R$. salmoninarum ATCC 33209 was quantified in microtitre plates (Dynatech). 
Bacteria were diluted in saline such that a 10 -fold dilution gave an $\mathrm{OD}_{600}$ of 0.56 . Doubling serial dilutions of the bacteria were made and $3 \%$ erythrocytes in saline were added to the bacterial dilutions. Plates were incubated at $20^{\circ} \mathrm{C}$ for $1 \mathrm{~h}$ and observed for haemagglutination. The haemagglutination titre was taken as the reciprocal of the last dilution that agglutinated the erythrocytes. Erythrocytes in saline served as the control. Bacteria that had been heat- or enzyme-treated were assayed for haemagglutination of rabbit erythrocytes on a glass slide; the degree of haemagglutination was scored as 0 (negative), 1 (weak), 2 (moderate) or 4 (strong). To test inhibition of haemagglutination by sugars, D-mannose, D-fucose, L-fucose, galactose and $N$-acetylglucosamine at $100 \mu \mathrm{g} \mathrm{ml} \mathrm{l}^{-1}$ were individually incubated for 30 min with bacteria, which were then reacted with $3 \%$ rabbit erythrocytes in microtitre plates as above.

Salt aggregation test for hydrophobicity $(S A T)$. The method of Lindahl et al. (1981) was used to determine whether $R$. salmoninarum strains were hydrophobic. Briefly, a stock solution of $2 \mathrm{M}$-ammonium sulphate in 2 mM-sodium phosphate ( $\mathrm{pH}$ 6.8) was diluted with 2 mM-sodium phosphate. When necessary, the resulting solutions were adjusted to $\mathrm{pH} 6.8$ with $1 \mathrm{M}$-ammonium hydroxide. The bacteria were suspended in $2 \mathrm{mM}$-sodium phosphate, such that a 50-fold dilution gave an $\mathrm{OD}_{600}$ of $0 \cdot 16$. Equal volumes of $25 \mu \mathrm{l}$ bacterial solution and ammonium sulphate solution were reacted on a glass slide and gently rocked for $2 \mathrm{~min}$ at room temperature. The reaction was considered positive when visible aggregation was seen as compared to bacterial suspensions in 2 mM-sodium phosphate. $R$. salmoninarum ATCC 33209 was tested at final ammonium sulphate concentrations ranging from $0.02 \mathrm{M}$ to $1 \mathrm{M}$; other strains were tested only at $0.25 \mathrm{M}$.

Bacterial adherence to hydrocarbons $(B A T H)$. Adherence to hydrocarbons was determined essentially according to the methods of Rosenberg et al. (1980). Untreated or enzyme-treated bacteria, at the cell density used for heat treatments, were added in $50 \mu \mathrm{l}$ volumes to tubes containing $2 \mathrm{ml}$ PUM buffer (containing, per litre, $22.2 \mathrm{~g}$ $\mathrm{K}_{2} \mathrm{HPO}_{4} .3 \mathrm{H}_{2} \mathrm{O}, 7.2 \mathrm{~g} \mathrm{KH}_{2} \mathrm{PO}_{4}, 1.8 \mathrm{~g}$ urea, $0.2 \mathrm{~g} \mathrm{MgSO}_{4} .7 \mathrm{H}_{2} \mathrm{O} ; \mathrm{pH} 7 \cdot 1$ ). The bacterial suspensions were then overlaid with $50,100,200$ or $400 \mu l$ hexadecane or $p$-xylene. The tubes were uniformly agitated on a vortex mixer for $1 \mathrm{~min}$, then allowed to sit for $15 \mathrm{~min}$ for phase separation. The decrease in the $\mathrm{OD}_{600}$ of the lower, aqueous, phase was used as a measure of cell-surface hydrophobicity. A suspension of untreated bacteria was also tested with hexadecane, in the presence of $1 \mathrm{M}$-ammonium sulphate.

Haemagglutinin hydrophobicity. Cells of $R$. salmoninarum ATCC 33209 were collected from 2-week KDM-C slants and washed three times in saline, then twice in distilled water. The two water extracts were pooled and filtered to remove any residual bacteria (Millipore, $0.45 \mu \mathrm{m}$ pore diameter). A $5 \mathrm{ml}$ volume of the extract was mixed with $5 \mathrm{ml} 2 \mathrm{M}$-ammonium sulphate and the total sample applied to phenyl-Sepharose CL-4B (Pharmacia) in a minicolumn, which consisted of a $15 \mathrm{~mm}$ Pasteur pipette with a $2.2 \mathrm{ml}$ bed volume. The column was washed with, in succession, $10 \mathrm{ml} 1 \mathrm{M}$-ammonium sulphate, $3.6 \mathrm{ml}$ saline, and $6 \mathrm{ml}$ water. The saline and water washes were collected in $200 \mu \mathrm{l}$ fractions and assayed for their ability to haemagglutinate rabbit erythrocytes in a slide reaction.

\section{RESULTS}

All 25 strains of $R$. salmoninarum autoaggregated in the liquid phase of the growth medium, as seen by microscopic examination. Autoaggregation was reversed when the bacteria were resuspended in a solution of low ionic strength, such as 2 mM-sodium phosphate, $\mathrm{pH} \mathrm{6.8.}$

All the strains haemagglutinated rabbit erythrocytes with a 4+ reaction on glass slides. In a quantitative microtitre plate test, $R$. salmoninarum ATCC 33209 gave a haemagglutination titre of 16 for rabbit erythrocytes, and of 4 for pigeon, horse and rat erythrocytes. Goat, sheep, calf, guinea-pig, chicken, rainbow trout, brook trout and coho salmon erythrocytes were not haemagglutinated. Spent growth medium, after removal of the bacteria, also caused haemagglutination of rabbit erythrocytes. The reaction was more pronounced with the supernatant fluid from cultures that were 4 weeks old than with that from 2-week cultures, whereas bacterial cells from the older cultures showed less haemagglutination. None of the sugars tested inhibited haemagglutination. After heating at $62^{\circ} \mathrm{C}$ or at $100^{\circ} \mathrm{C}$ and resuspension, bacterial cells had reduced haemagglutinating ability (Table 2 ). However, the supernatant fluids collected from the heated cells did haemagglutinate rabbit erythrocytes. The material from bacteria heated at $100^{\circ} \mathrm{C}$ for $40 \mathrm{~min}$ was less active than that from bacteria heated for $20 \mathrm{~min}$. Thus, while a haemagglutinin could be extracted from cells by heat treatment, overheating appeared to destroy its activity.

All the strains aggregated readily in $0.25 \mathrm{M}$-ammonium sulphate, indicative of a hydrophobic surface. $R$. salmoninarum ATCC 33209 adsorbed readily to the hydrophobic hydrocarbon hexadecane (Fig. 1) and equally well to $p$-xylene (data not shown). In the presence of $1 \mathrm{M}$ - 


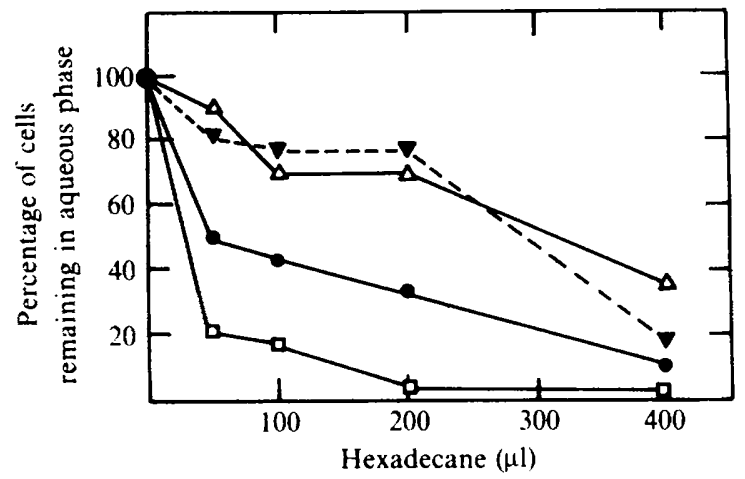

Fig. 1. Partition of R. salmoninarum ATCC 33209 to hexadecane and aqueous phases in the BATH test for hydrophobicity. Uniform amounts of bacterial suspensions were mixed with different volumes of hexadecane. The proportion of the cells remaining in the aqueous phase after $15 \mathrm{~min}$ was determined by comparing the $\mathrm{OD}_{600}$ reading with that of the original suspension. Cell pre-treatments were: ${ }$, none: $\boldsymbol{\nabla}$, trypsin; $\triangle$, protease $\mathrm{K} ; \square$, suspension in $1 \mathrm{M}-\left(\mathrm{NH}_{4}\right)_{2} \mathrm{SO}_{4}$. The test was repeated 3 times; the results shown are from a representative experiment.

Table 2. Effects of heating and protease treatment on hydrophobicity and haemagglutination activity of $R$. salmoninarum

\begin{tabular}{|c|c|c|c|}
\hline \multirow[b]{2}{*}{ Treatment* } & \multirow{2}{*}{$\begin{array}{r}\text { Salt aggregation } \dagger \\
{\left[\left(\mathrm{NH}_{4}\right)_{2} \mathrm{SO}_{4}, \mathrm{M}\right]}\end{array}$} & \multicolumn{2}{|c|}{ Haemagglutination $\neq$ by: } \\
\hline & & Cells & Culture supernate \\
\hline None & 0.03 & $4+$ & 0 \\
\hline $62^{\circ} \mathrm{C}, 40 \mathrm{~min}$ & $>1$ & $1+$ & $3+$ \\
\hline $100^{\circ} \mathrm{C}, 20 \mathrm{~min}$ & $>1$ & 0 & $2+$ \\
\hline $100^{\circ} \mathrm{C}, 40 \mathrm{~min}$ & $>1$ & 0 & $1+$ \\
\hline Trypsin $\left(1 \mathrm{mg} \mathrm{ml}^{-1}\right)$ & $0 \cdot 06$ & $4+$ & 0 \\
\hline Protease $\mathrm{K}\left(1 \mathrm{mg} \mathrm{ml}^{-1}\right)$ & $0 \cdot 3$ & $4+$ & 0 \\
\hline
\end{tabular}

* Cell suspensions were pre-treated as indicated. Further details are given in Methods.

+ The salt aggregation test (SAT) was as described by Lindahl et al. (1981).

$\ddagger$ Haemagglutination of rabbit erythrocytes was tested by slide agglutination and scored as 0 (negative), 1 (weak). 2 (moderate) or 4 (strong). Cells were separated from their suspending fluid after treatment, and the resuspended cells and the fluid tested independently.

ammonium sulphate, adsorption of the bacteria increased. Heating and enzyme treatment of the bacteria decreased their hydrophobicity (Fig. 1, Table 2).

The haemagglutinating activity could also be extracted from the bacteria by washing with distilled water. In the presence of $1 \mathrm{M}$-ammonium sulphate, the extracted haemagglutinin bound to phenyl-Sepharose and was eluted from the column at approximately the saline-water interface. This suggests that the haemagglutinin may be, at least in part, responsible for the hydrophobic nature of the surface of $\boldsymbol{R}$. salmoninarum. Bacterial cells that had been treated with heat or protease $\mathbf{K}$, or from which the haemagglutinin had been extracted with water, demonstrated decreased hydrophobicity, staying in suspension while untreated cells readily settled to the bottom of the test tubes.

\section{DISCUSSION}

All 25 strains of $R$. salmoninarum tested haemagglutinated rabbit erythrocytes and were hydrophobic, regardless of their geographic or fish species source. Thus, in these characteristics as well as others, isolates of $R$. salmoninarum are relatively homogeneous (Bullock et al., 1974; Bruno \& Munro, 1986; Fiedler \& Draxl, 1986). The hydrophobic nature of the cell surface explains several previously noted growth phenomena (see Introduction). The decrease in 
hydrophobicity after heating the bacteria at $62^{\circ} \mathrm{C}$ explains the observation of Evelyn et al. (1973), that this pre-treatment prevents autoaggregation.

Binding of the haemagglutinin to the hydrophobic gel phenyl-Sepharose indicates that this active component is partially responsible for the hydrophobic nature of the cell surface. Since it can be removed from the bacteria by placing them in water, it must be non-covalently attached, perhaps by hydrophobic or ionic interactions. The hydrophobicity of the bacteria was reduced by enzyme treatment while the haemagglutinin was not affected, suggesting that different molecules, or different sites on the same molecule, are responsible for these activities. The haemagglutinin may be a bacterial lectin, one of the proteinaceous compounds, such as pili, that bind specifically to sugar receptors (Wadstrom \& Trust, 1984). None of the sugars we tested inhibited agglutination of rabbit erythrocytes, but the receptor may contain different simple sugars, or more complex sugars. Transmission electron microscopic examination of cells of $R$. salmoninarum ATCC 33209 negatively stained with ammonium molybdate or uranyl acetate did not reveal any structures, such as pili or a protein surface array, that might account for the hydrophobic nature of the renibacterial surface (data not shown).

The haemagglutinin and hydrophobic surface of $R$. salmoninarum may be important virulence factors. They could facilitate uptake into macrophages, where Young \& Chapman (1978) have suggested $R$. salmoninarum survives and possibly replicates. Such surface features could also be involved in the invasion of salmonid ova, allowing for the vertical transmission of bacterial kidney disease, as described by Evelyn et al. (1984). Austin \& Rayment (1985) have suggested that $R$. salmoninarum may survive in the environment, external to salmonid fish, for short periods. The hydrophobic nature of the bacterium would cause it to leave the water column and attach to surfaces.

A significant aspect of the reported work is the relationship of the haemagglutinin of $R$. salmoninarum to antigens used in serodiagnostics. The extraction of the haemagglutinin from $R$. salmoninarum at $100^{\circ} \mathrm{C}$ is reminiscent of the extraction procedure used to obtain an antigen from infected tissues. The PAP technique (Sakai et al., 1987), ELISA technique (Pascho \& Mulcahy, 1987), and immunodiffusion (Chen et al., 1974), coagglutination (Kimura \& Yoshimizu, 1981) and counter-immunoelectrophoresis (Cipriano et al., 1985) procedures all similarly extract the bacterial antigen from infected tissue by boiling. Getchell et al. (1985) described a soluble antigen that was found on the surface of $R$. salmoninarum, designated the F-antigen. It was heatstable and could be concentrated by its exclusion by a membrane filter with a $100 \mathrm{kDa}$ cutoff. The haemagglutinin examined here is also heat stable and can be similarly concentrated (data not shown), suggesting that it may be the F-antigen. The extraction of the haemagglutinin in water provides a simple way of obtaining this molecule for purification and immunological studies. We are currently purifying the haemagglutinin of $R$. salmoninarum, in order to determine whether it is indeed the antigen being detected in the various serodiagnostic procedures.

We thank the individuals who provided bacterial strains for this study, and R. J. Doyle for helpful discussions. The Ontario Ministry of Natural Resources provided financial support for this work. J.G.D. gratefully acknowledges an Olin Fellowship from the Atlantic Salmon Federation.

\section{REFERENCES}

Austin, B. \& RAYMENT, J. N. (1985). Epizootiology of Renibacterium salmoninarum, the causative agent of bacterial kidney disease in salmonid fish. Journal of Fish Diseases 8, 505-509.

Austin, B., Bucke, D., Feist, S. \& Rayment, J. (1985). A false positive reaction in the indirect fluorescent antibody test for Renibacterium salmoninarum with a 'coryneform' organism. Bulletin of the European Association of Fish Pathologists 5, 8-9.

BRUNo, D. W. \& MUNRO, A. L. S. (1986). Uniformity in the biochemical properties of Renibacterium salmoninarum isolates obtained from several sources. FEMS Microbiology Letters 33, 247-250.

Bullock, G. L., Stuckey, H. M. \& Chen, P. K. (1974). Corynebacterial kidney disease of salmonids: growth and serological studies on the causative bacterium. Applied Microbiology 28, 811-814.

Chen, P. K., Bullock, G. L., StuCKey, H. M. \& Bullock, A. C. (1974). Serological diagnosis of corynebacterial kidney disease of salmonids. Journal of the Fisheries Research Board of Canada 31, 19391940. 
Cipriano, R., Starliper, C. E. \& Schachte, J. H. (1985). Comparative sensitivities of diagnostic procedures used to detect bacterial kidney disease in salmonid fishes. Journal of Wildlife Diseases 21, 144148.

Daly, J. G. \& Stevenson, R. M. W. (1985). Charcoal agar, a new growth medium for the fish disease bacterium Renibacterium salmoninarum. Applied and Entironmental Microbiology 50, 868-871.

Embley, T. M., Goodfellow, M. \& Austin, B. (1982). A semi-defined medium for Renibacterium salmoninarum. FEMS Microbiology Letters 14, 299-301.

EVELYN, T. P. T. (1977). An improved growth medium for the kidney disease bacterium and some notes on using the medium. Bulletin de l'Office International des épizooties 87, 511-513.

Evelyn, T. P. T., Hoskins, G. E. \& Bell, G. R. (1973). First record of bacterial kidney disease in an apparently wild salmonid in British Columbia. Journal of the Fisheries Research Board of Canada 30, $1578-1580$.

Evelyn, T. P. T., Ketcheson, J. E. \& ProsperjPorta, L. (1981). The clinical significance of immunofluorescence-based diagnoses of the bacterial kidney disease carrier. Fish Pathology 15, 293300.

Evelyn, T. P. T., Ketcheson, J. E. \& ProsperiPORTA, L. (1984). Further evidence for the presence of Renibacterium salmoninarum in salmonid eggs and the failure of proidone-iodine to reduce the intraovum infection rate in water-hardened eggs. Journal of Fish Diseases 7, 173-182.

FIEDLER, F. \& DRAXL, R. (1986). Biochemical and immunochemical properties of the cell surface of Renibacterium salmoninarum. Journal of Bacteriology 168, 700-804.

FRYER, J. L. \& SANDERS, J. E. (1981). Bacterial kidney disease of salmonid fish. Annual Review of Microbiology 35, 273-298.

Getchell, R. G., Rohovec, J. S. \& Fryer, J. L. (1985). Comparision of Renibacterium salmoninarum jsolates by antigenic analysis. Fish Pathology 20, 149-159.
Kimura, T. \& Yoshimizu, M. (1981). A coagglutination test with antibody sensitized staphylococci for rapid and simple diagnosis of bacterial kidney disease (BKD). Developments in Biological Standardization 49, 135-148.

Lindahl, M., Faris, A., Wadstrom, T. \& HJeRTEN, S. (1981). A new test based on 'salting out' to measure relative surface hydrophobicity of bacterial cells. Biochimica et biophysica acta 677, 471-476.

McCarthy, D. H., Croy, T. R. \& Amend, D. E. (1984). Immunization of rainbow trout, Salmo gairdneri Richardson, against bacterial kidney disease: preliminary efficacy evaluation. Journal of Fish Diseases 7, 65-71.

Pascho, R. J. \& Mulcahy, D. (1987). Enzyme-linked immunosorbent assay for a soluble antigen of Renibacterium salmoninarum, the causative agent of salmonid bacterial kidney disease. Canadian Journal of Fisheries and Aquatic Sciences 44, 183-191.

Rosenberg, M., Gutnick, D. \& RosenberG, E. (1980). Adherence of bacteria to hydrocarbons: a simple method for measuring cell-surface hydrophobicity. FEMS Microbiology Letters 9, 29-33.

Sakai, M., Koyama, G., Atsuta, S. \& Kobayashi, M. (1987). Detection of Renibacterium salmoninarum by a modified peroxidase-antiperoxidase (PAP) procedure. Fish Pathology 22, 1-5.

SANDERS, J. E. \& Fryer, J. L. (1980). Renibacterium salmoninarum gen. nov., sp. nov., the causative agent of bacterial kidney disease in salmonid fishes. International Journal of Systematic Bacteriology 30, 496-502.

Smith, I. W. (1964). The occurrence and pathology of Dee disease. Freshwater Salmon Research 34, 1-12.

Van Oss, C. J. (1978). Phagocytosis as a surface phenomenon. Annual Review of Microbiology 32, 19 39.

W ADSTROM, T. \& TRUST, T. J. (1984). Bacterial surface lectins. Medical Microbiology 4, 287-334.

YounG, C. L. \& Chapman, G. B. (1978). Ultrastructural aspects of the causative agent and renal histopathology of bacterial kidney disease in brook trout (Salvelinus fontinalis). Journal of the Fisheries Research Board of Canada 35, 1234-1248. 